\title{
Immunoactive trypsins in duodenal juice from children with gastrointestinal disorders
}

\author{
S BORULF* and T LINDBERG \\ From the Department of Paediatrics and Department of Experimental Research, Malmö General Hospital, \\ University of Lund, Malmö, Sweden
}

SUMmaRY Duodenal juice contains two trypsins, one anionic and one cationic at pH 8.6. To investigate their distribution, we studied fasting specimens of duodenal juice from 89 children with different gastrointestinal problems. The two trypsins were separately determined with electroimmunoassay parallel with determinations of total trypsin esterolytic activity and total protein. In 81 children with normal pancreatic function the ratio immunoactivity: esterolytic activity averaged $3 \cdot 25: 1$. Anionic trypsin comprised an average $12 \%$ of immunoactivity: the average trypsin contribution to the total protein content was $37 \%$ for immunoactivity and $12 \%$ for esterolytic activity. These ratios were not influenced by age. Fourteen children with coeliac disease had significantly lower mean values for trypsins and total protein. Eight children with pancreatic insufficiency had discrepant trypsin distribution, anionic trypsin being the dominant residuum in five of the eight.

Human duodenal juice has been shown to have two forms of trypsin, ${ }^{1}$ one with cathodal and one with anodal mobility in agarose gel electrophoresis at $\mathrm{pH}$ 8.6. The interrelation of these two trypsins in pancreatogenic and enterogenic malabsorption syndromes and also in different age groups is obscure. Moreover, the ratio immunoactive trypsin: esterolytically active trypsin in various malabsorption syndromes with and without pancreatic insufficiency is incompletely known. In a preliminary study ${ }^{2}$ we found this ratio to be three times higher in a child with pancreatic insufficiency than in seven children with enterogenic malabsorption.

This study determined immunochemically the two trypsins and also compared the amounts of immunoactive trypsin with the amounts of esterolytically active trypsin in duodenal juice from eight children with pancreatic insufficiency and from 81 children of various ages and various gastrointestinal disorders.

\section{Methods}

\section{PATIENTS}

The study group consisted of 89 children, 48 boys and 41 girls, aged 6 weeks to 8 years, who in the course of four years were submitted to gastroenterological examination at the Department of Paediatrics for suspected malabsorption with signs of poor weight gain and/or stool problems. None of the children was acutely ill and none received parenteral nutrition when investigated. None of the patients had a severe malnutrition. Additional details are given in Table 1 . The examination programme ${ }^{3}$ included - apart from the routine clinical and laboratory examination - intestinal mucosal biopsy, duodenal juice aspiration, and faecal microscopy. Pancreatic function was assessed from duodenal juice analyses, including determination of amylase and trypsin activities together with agarose gel electrozymogram. ${ }^{13}$

COLLECTION OF DUODENAL JUICE

All patients received Alimemazine* $2 \mathrm{mg} / \mathrm{kg}$ body weight two hours before intubation. Duodenal juice was collected under identical conditions in all the patient groups into tubes of crushed ice via a double lumen tube ${ }^{3}$ (Salem Sump Fr Size $10 \mathrm{Ch}$ ) from a position immediately proximal to the duodenojejunal flexure (fluoroscopic control). All samples were collected in the fasting state and kept frozen at

\footnotetext{
* Address for correspondence: Dr S Borulf, Department of Paediatrics, Malmö General Hospital, S-214 01 Malmö, Sweden.

Received for publication 20 November 1981
} 


\begin{tabular}{|c|c|c|c|c|c|c|c|}
\hline \multirow[b]{2}{*}{ Diagnostic groups } & \multirow[b]{2}{*}{$n$} & \multirow{2}{*}{$\begin{array}{l}\text { Age (months) } \\
\text { mean (range) }\end{array}$} & \multirow{2}{*}{$\begin{array}{l}\text { Weight deficit } \\
(\triangle S D) \text { (mean value) }\end{array}$} & \multicolumn{4}{|c|}{ Small intestinal mucosa } \\
\hline & & & & Flat & Convoluted & Ridged & Villous \\
\hline $\begin{array}{l}\text { Shwachman's syndrome } \\
\text { Cystic fibrosis }\end{array}$ & $\begin{array}{l}2 \\
6\end{array}$ & $20(1-84)$ & & & & & \\
\hline $\begin{array}{l}\text { Coeliac disease* } \\
\text { Cow's milk protein }\end{array}$ & 14 & $11(6-22)$ & $-1 \cdot 83$ & 14 & 0 & 0 & 0 \\
\hline $\begin{array}{l}\text { intolerance } \dagger \\
\text { Unclassified gastrointestinal }\end{array}$ & 33 & $12(1-36)$ & -1.67 & 0 & 6 & 16 & 11 \\
\hline disorders $\ddagger$ & 34 & $25(5-96)$ & -1.48 & 0 & 3 & 18 & 13 \\
\hline
\end{tabular}

* Diagnostic criteria: flat mucosa on a gluten-containing diet, clinical and histological improvement on gluten-free diet, and histological relapse when gluten was reintroduced in the diet. ${ }^{26}$

$\dagger$ Diagnostic criteria: free of symptoms on a cow's milk-free diet, and return of identical symptoms at two challenges with cow's milk.

$\ddagger$ Failure to thrive, vomiting, and/or diarrhoea for more than three weeks, with normal laboratory tests. Symptoms disappearing within a few months.

$-20^{\circ} \mathrm{C}$ until analysed. As described earlier ${ }^{2}$ control studies have shown that no significant losses of activity - immunologocial or enzymatical - occur under these conditions. $\mathrm{pH}$ of all samples was 6 or more.

The study was approved by the Ethical Committee of the University of Lund.

\section{MATERIALS}

Agarose was purchased from Marine Colloids Inc; Miles Lab. Ltd., Stoke Poges, UK, n-benzoyl-DLarginine-p-nitro-anilide (BAPNA), p-nitrophenylpara'-guanidinobenzoate- $\mathrm{HCl}$ and bovine albumin from Sigma Chemicals, St. Louis, USA, Phadebas amylase test from Pharmacia, Uppsala, Sweden.

Rabbit antisera against anodal and cathodal human trypsins and DFP-inactivated purified human anodal and cathodal trypsins were produced at our laboratory. ${ }^{2}$

\section{TECHNIQUES}

\section{Enzyme activity}

Trypsin esterolytic activity was measured with BAPNA as a substrate ${ }^{4}$ and with the purified human trypsins as standards. ${ }^{2}$ Amylase activity was assayed with Phadebas amylase test. ${ }^{5}$ Active site titration of the purified trypsin preparations was performed according to Bender ${ }^{6}$ with p-nitrophenyl-para'guanidinobenzoate- $\mathrm{HCl}$ as substrate.

\section{Immunochemical activity}

Anodal and cathodal immunoactive trypsins were determined with the rocket technique of electroimmunoassay, ${ }^{7}$ as described earlier, ${ }^{2}$ at $\mathrm{pH}$ 8.6 in $0.8 \%$ agarose gel containing rabbit antibodies against anodal and cathodal human trypsins (1\% for antianodal, $0.4 \%$ for anticathodal) and with the DFP-inactivated purified human trypsins as standards.

\section{Agarose gel electrophoresis}

This was run in $\mathrm{pH} 8 \cdot 6 .^{1}$

\section{Protein determinations}

These were performed according to Lowry et $a l^{8}$ with bovine albumin as standard.

\section{Statistical evaluation}

Correlation and regression coefficients were calculated according to Hald. ${ }^{9} r=0.25$ was considered lower limit for covariance. Comparison of diagnostic groups was made by Student's $t$ test.

\section{Results}

Table 2 lists the results of enzyme assays for the patients with coeliac disease, cow's milk protein intolerance, and unclassified gastrointestinal disorder. No significant difference was found between the patients with unclassified gastrointestinal disorder and those with cow's milk protein intolerance. The children with coeliac disease had amounts of anodal and cathodal trypsins, of esterolytic active trypsin, and of total protein lower than the other two groups $(p<0.01)$. The ratio immunoactivity: enzymatic activity averaged 3.25:1. Active site titrations estimated $97 \%$ of the protein in the purified preparations to be active. Anionic trypsin comprised on average $12 \%$ of duodenal juice immunoactivity. The two trypsins contributed to total protein content by $37 \%$ as measured by immunoactivity, by $12 \%$ if measured enzymatically.

No age variation was found in esterolytic activity or immunoactivity of anodal and cathodal trypsins.

The duration of the storage of duodenal juice in $-20^{\circ} \mathrm{C}$ before analysis (varying from three hours to two years) had no demonstrable influence on the amounts of immunoactive anodal and cathodal trypsins, or on the amounts of esterolytically active 
Table 2 Trypsin concentration and total protein, mean $( \pm S D)$ (range), in duodenal juice from patients with coeliac disease, cow's milk protein intolerance, and unclassified gastrointestinal disorder

\begin{tabular}{|c|c|c|c|}
\hline & $\begin{array}{l}\text { Coeliac disease } \\
n=14\end{array}$ & $\begin{array}{l}\text { Cow's milk } \\
\text { intolerance } \\
n=33\end{array}$ & $\begin{array}{l}\text { Unclassified } \\
\text { malabsorption } \\
n=34\end{array}$ \\
\hline \multicolumn{4}{|l|}{ Immunoactivity } \\
\hline Anionic (A) (g/l) & $\begin{array}{l}0.14 \begin{array}{l}(0.08) \\
(0.03-0.30)\end{array}\end{array}$ & $\begin{array}{l}0.21(0.13) \\
(0.04-0.46)\end{array}$ & $\begin{array}{l}0.24(0.11) \\
(0.07-0.65)\end{array}$ \\
\hline Cationic (B) (g/l) & $\begin{aligned} 1.64 & (0.78) \\
& (0.42-2.85)\end{aligned}$ & $\begin{aligned} & 2.21(1.38) \\
&(0.36-6.57)\end{aligned}$ & $\begin{aligned} 2 \cdot 14 & (1 \cdot 40) \\
& (0 \cdot 14-7 \cdot 23)\end{aligned}$ \\
\hline Total $(\mathrm{g} / \mathrm{l})$ & $\begin{aligned} & 1.78(0.81) \\
&(0.58-3.00)\end{aligned}$ & $\begin{aligned} & 2.42(1.40) \\
&(0.40-6.90)\end{aligned}$ & $\begin{aligned} 2.38 & (1.41) \\
& (0 \cdot 26-7 \cdot 42)\end{aligned}$ \\
\hline $\mathbf{A} / \mathbf{A}+\mathbf{B}$ ratio & $\begin{array}{l}0.09(0.02) \\
\quad(0.03-0.27)\end{array}$ & $\begin{array}{l}0.11(0.08) \\
\quad(0.02-0.40)\end{array}$ & $\begin{array}{l}0.13(0.09) \\
\quad(0.02-0.46)\end{array}$ \\
\hline \multicolumn{4}{|l|}{ Esterolytic activity } \\
\hline BAPNA (g/l) & $\begin{aligned} 0.49 & (0.20) \\
& (0.17-0.93)\end{aligned}$ & $\begin{array}{l}0.73(0.31) \\
\quad(0.23-1.37)\end{array}$ & $\begin{aligned} & 0 \cdot 81(0 \cdot 37) \\
&(0 \cdot 18-1 \cdot 84)\end{aligned}$ \\
\hline Immunoactivity: esterolytic activity & $\begin{aligned} 3.77 & (1.43) \\
& (1.45-5.41)\end{aligned}$ & $\begin{array}{l}3.29(1.21) \\
\quad(1.03-6.48)\end{array}$ & $\begin{aligned} 3.00 & (1.24) \\
& (1.49-7.75)\end{aligned}$ \\
\hline Total protein $(\mathrm{g} / \mathrm{l})$ & $\begin{aligned} 4 \cdot 37(1 \cdot 69) \\
(2 \cdot 1-9 \cdot 1)\end{aligned}$ & $\begin{array}{c}6.05(1 \cdot 70) \\
(2 \cdot 0-9 \cdot 4)\end{array}$ & $\begin{aligned} 6.97 & (1 \cdot 80) \\
& (4 \cdot 0-10 \cdot 8)\end{aligned}$ \\
\hline Immunoactive trypsin: total protein & 0.41 & 0.40 & $0 \cdot 37$ \\
\hline
\end{tabular}

trypsin.

Control experiments comparing duodenal juice specimens collected in fasting state and after intake of a test meal of water $(50-300 \mathrm{ml}$ depending on age) did not reveal any differences for the interrelation between anodal and cathodal trypsins or for the ratio immunoactive: esterolytically active trypsins.

Table 3 lists the results for the group with pancreatic insufficiency. Unlike the patients without pancreatic disease (Table 2), this group does not show any uniformity in the relation between the two trypsins. Anionic trypsin was the only detectable one in four patients and was predominant in another. In three patients with assayable immuno-

Table 3 Trypsins and total protein in duodenal juice from patients with pancreatic insufficiency

\begin{tabular}{|c|c|c|c|c|c|c|}
\hline \multirow[b]{2}{*}{$\begin{array}{l}P t^{*} \\
\text { no. }\end{array}$} & \multirow[b]{2}{*}{$\begin{array}{l}\text { Age } \\
(y r)\end{array}$} & \multirow{2}{*}{$\begin{array}{l}\text { Esterolytic } \\
(B A P N A) \\
(g / l)\end{array}$} & \multicolumn{2}{|c|}{ Immunoactive } & \multirow{2}{*}{$\begin{array}{l}\text { Immunoactive } \\
\text { esterolytic } \\
\text { ratio }\end{array}$} & \multirow{2}{*}{$\begin{array}{l}\text { Total } \\
\text { protein } \\
(\mathrm{g} / \mathrm{l})\end{array}$} \\
\hline & & & $\begin{array}{l}\text { Anionic } \\
(g / l)\end{array}$ & Cationic & & \\
\hline 1 & 7 & 0.03 & 0.03 & 0.11 & $4 \cdot 67$ & $2 \cdot 2$ \\
\hline 2 & 312 & 0.05 & 0.07 & 0.14 & 3.96 & $5 \cdot 0$ \\
\hline 3 & 1 & 0.03 & 0.04 & 0 & $1 \cdot 33$ & 0.9 \\
\hline 4 & $\frac{1}{12}$ & 0.01 & 0.02 & 0 & 1.67 & $2 \cdot 4$ \\
\hline 5 & $1 \frac{5}{12}$ & 0 & 0.01 & 0.15 & - & $11 \cdot 8$ \\
\hline 6 & $\begin{array}{l}7 \\
12\end{array}$ & 0.03 & 0.07 & 0.01 & $2 \cdot 75$ & 1.9 \\
\hline 7 & $\begin{array}{l}1 \\
12\end{array}$ & 0 & 0.01 & 0 & - & 2.7 \\
\hline 8 & $\frac{1}{12}$ & 0 & 0.03 & 0 & - & $10 \cdot 8$ \\
\hline
\end{tabular}

* Diagnoses: patients nos 1, 2: Shwachman syndrome. Patients nos 3-8: cystic fibrosis. activity, no trypsin was detected by assaying esterolytic activity only.

\section{Discussion}

Control experiments reported here and earlier ${ }^{1}$ revealed no differences for the interrelations of the presented parameters between stimulated (test meal of water or pancreozymin) and fasting condition. Lebenthal and Lee ${ }^{10}$ demonstrated that in children below 2 years of age the fasting value of trypsin was as high as that after pancreozymin administration. This finding agrees with our experience, ${ }^{1}$ which also included stimulation with a test meal. In view of the aims of this study, we chose to analyse juice in fasting condition, this being the most suitable and reproducible condition for routine clinical work.

Literature has few reports on fasting values of trypsin activity in children; a comparison is hampered by variance in assay methods and standards used. However, the trypsin values obtained in this study are of the same magnitude as reported by Lebenthal and Lee, ${ }^{10}$ Simar et al, ${ }^{11}$ Shapiro et al, ${ }^{12}$ Hermier et al. ${ }^{13}$

In this connection, it is worth noting that we found agreement between the BAPNA activities for human and bovine trypsin providing that protein concentrations for both standards were determined chemically. Our bovine trypsin preparations had a ratio $1 \cdot 4: 1$ between protein concentrations determined chemically and concentrations determined by weight. ${ }^{2}$ 
The lack of demonstrable influence by age on all the studied parameters is well documented for the esterolytic activity. ${ }^{10} 1114$ No comparable data for the immunoactivities were found.

In a pilot study with nine children, we reported a proportion of $20 \%$ for anionic trypsin. ${ }^{2}$ In this larger material, the proportion averaged $12 \%$, a figure more closely agreeing with those reported for pancreatic juice. ${ }^{15-17}$ Although a smaller figure, it indicates a significant role in digestion for the anionic trypsin. This presumption is further sustained by the proportionately higher proteolytic (casein hydrolysing) and BAPNA splitting activity per gram protein for anionic trypsin than for cationic trypsin (a ratio of 44:56 and 46:54, respectively). ${ }^{2}$

The anionic trypsin is as stable as the cationic in duodenal juice, but it is remarkably unstable in purified form. ${ }^{2}$ This suggests the presence of some stabilising factor in duodenal juice. Colomb et al ${ }^{17}$ reported that the addition of $20 \mathrm{mmol} / \mathrm{l}$ calcium to duodenal juice will further stabilise the enzymes at $37^{\circ} \mathrm{C}$.

The estimates of total trypsin immunoactivity and BAPNA-splitting activity in 81 children display a constant discrepancy of varying degree with a ratio averaging $3 \cdot 25: 1$. This ratio was $1 \cdot 6: 1$ in the pilot study $^{2}$ but this comprised only seven children. Shapiro et $a l^{12}$ reported for cationic trypsin, determined with radial immunodiffusion technique, a corresponding ratio ranging from $1 \cdot 02: 1$ to $3 \cdot 4: 1$, whereas our ratio range is 1.05 to $7 \cdot 31: 1$. For adults Lake-Bakaar et $a^{18}$ reported a ratio 1.5:1 for radio-immunoactivity (cationic trypsin) to total enzymatic activity (substrate: p-tosyl-l-arginine methyl ester). These discrepancies are probably due to differences in methods; moreover, our figures also include the anionic trypsin. The results indicate the presence of considerable and variable amounts of inactive forms of the enzymes. These may be the result of (1) complex-formation with protease inhibitors, ${ }^{19}{ }^{20}$ (2) spontaneous inactivation by autocatalysis of properly activated zymogens, ${ }^{17}$ and (3) spontaneous formation of inert proteins under unfavourable activation conditons such as the presence of inadequate amounts of enterokinase. ${ }^{21}$

The distribution of the immunoactivity: BAPNA activity ratio was the same in the different patient groups without pancreatic disease (Table 2); but the amounts of trypsin assayed by both methods was lower in the coeliac group.

Trypsin in fasting condition has been reported to be decreased ${ }^{22}$ or unaltered ${ }^{2324}$ in coeliac children. Coeliac children with severe malnutrition had decreased values. ${ }^{23}$ In our study the coeliac disease was diagnosed at an early stage of the disease and severe malnutrition had not yet ensued. It seems, therefore, most plausible that the low enzyme and protein concentration may be due to an increased proportion of water. A possible explanation for the latter circumstance was offered by Polak et al, ${ }^{25}$ demonstrating hyperactivity in secretin-producing cells in the intestinal mucosa in coeliac disease.

From the results for the eight patients with pancreatic insufficiency, we can extract: first, despite 'near-zero' values for trypsin activity, considerable amounts of immunoactive trypsin can be demonstrated; second, the cationic trypsin seems to be the first to disappear completely. This might be due to an increased vulnerability of the synthesis of the cationic trypsin or to a decreased stability of this enzyme under these conditions. Further studies on a larger number of patients of this category may clarify whether this discrepancy can enable us to detect earlier stages of deterioration in pancreatic function.

We are much indebted to Mrs M Månsson and Mrs B Benediktsson for excellent technical assistance. This work was supported by The Swedish Medical Research Council (grant 5143 and 5364), The Swedish Baby Food Industry Fund for Nutritional Research, Semper Nutrition Foundation, and The Albert Påhlsson Fund.

\section{References}

1 Borulf S, Lindberg T, Hansson L. Agarose gel electrophoresis of duodenal juice in normal condition and in children with malabsorption. Scand J Gastroenterol 1979; 14: 151-60.

2 Borulf S, Lindberg T, Benediktsson B, Månsson $M$. Immunochemical determination of two trypsins in human duodenal juice. Clin Chim Acta 1979; 94: 51-62.

3 Berg NO, Borulf S, Jakobsson I, Lindberg T. How to approach the child suspected of malabsorption. Acta Paediatr Scand 1978; 67: 403-11.

4 Erlanger BF, Kokowsky N, Cohen W. The preparation and properties of two new chromogenic substrates of trypsin. Arch Biochem Biophys 1961; 95: 271-8.

5 Ceska M, Hultman E, Ingelman BG. A new method for determination of $\propto$-amylase. Experienta 1969; 25: 555-61.

6 Bender ML. The determination of the concentration of hydrolytic enzyme solutions. J Am Chem Soc 1966; 88: 5890-913.

7 Laurell C-B. Electroimmunoassay. Scand J Clin Lab Invest 1972; 29: suppl 124:21-37.

8 Lowry OH, Rosebrough NJ, Farr AL, Randall RJ. Protein measurement with the Folin phenol reagant. $J$ Biol Chem 1951; 193: 265-75.

9 Hald A. Statistical theory with applications. New York: Wiley, 1960. 
10 Lebenthal E, Lee PC. Development of functional response in human exocrine pancreas. Pediatrics 1980; 66: $556-60$.

11 Simar J, Louis-Leclercq MP, Farriaux JP. La secretion pancreatique exocrine chez l'enfant. Lille Med 1973; 18: 405-22.

12 Shapiro E, Arnon R, Russel A. Specific immunoassay for quantitative determination of human trypsin in intestinal content. J Lab Clin Med 1971; 77: 877-84.

13 Hermier M, Mathieu M, Fillat M, Gilly R, Chazalette JP, Cotte J. Etude de la fonction pancreatique exocrine dans la mucoviscidose. Rev Fr Étud Clin Biol 1969; 14: 867-84.

14 Delachaume-Salem E, Sarles H. Evolution en fonction de l'age de la sécrétion pancreatique humaine normale. Biol Gastroenterol 1970; 11: 135-46.

15 Robinson LA, Kim WJ, White TT, Hadorn B. Trypsins in human pancreatic juice - their distribution as found in 34 specimens. Scand J Gastroenterol 1972; 7: 43-5.

16 Mallory PA, Travis J. Human pancreatic enzymes. Characterization of anionic trypsin. Biochemistry 1973; 12: 2847-51.

17 Colomb E, Guy O, Deprez P, Michel R, Figarella C. The two human trypsinogens: catalytic properties of the corresponding trypsins. Biochem Biophys Acta 1978; 525: 186-93.

18 Lake-Bakaar G, McKavanagh S, Rubio CE, Epstein
O, Summerfield JA. Measurement of trypsin in duodenal juice by radioimmunoassay. Gut 1980; 21: 402-7.

19 Borulf S, Lindberg T. Protease inhibitors in duodenal juice from children with malabsorption. Clin Chim Acta 1981; 112: 253-5.

20 Pubols MH, Bartelt DC, Greene LJ. Trypsin inhibitor from human pancreas and pancreatic juice. J Biol Chem 1974; 249: 2235-42.

21 Kunitz M. Effect of formation of inert protein on kinetics of autocatalytic formation of trypsin from trypsinogen. J Gen Physiol 1939; 22: 293-310.

22 McDougall C. Clinical evaluation of abnormal enzyme content in the pancreatic juice of children. Pediatrics 1950; 5: 114-25.

23 Andersen DN. Pancreatic enzymes in the duodenal juice in the celiac syndrome. Am J Dis Child 1942; 63: $643-58$.

24 Farber S, Shwachman H, Muddock CL. Pancreatic function and disease in early life. I. Pancreatic enzyme activity and the celiac syndrome. J Clin Invest 1943; 22: 827-38.

25 Polak JM, Pearse AGE, Van Norden S. Secretin cells in coeliac disease. Gut 1973; 14: 870-4.

26 European Society for Paediatric Gastroenterology: Diagnostic criteria in coeliac disease. Acta Paediatr Scand 1970; 59: 461-63. 